\title{
Value at Risk as a Measurement of Market Risk in Emerging Sharia Market: A Comparative Study Between Indexes in Indonesian Stock Exchange
}

\section{Baiq Nurul Suryawati and Lalu Unsun-Nidhal²}

${ }^{1}$ Department of Management, Faculty of Economic and Bussiness, University of Mataram, Jln. Majapahit No 62 Mataram 83127-Indonesia

${ }^{2}$ Center for Biotechnology Studies, Gadjah Mada University, Yogyakarta-Indonesia, Jl. Teknika Utara, Yogyakarta 55281, Indonesia

\section{Abstract}

As far it goes, risk measurement relies on standard deviation. It calculates how the current event diverse from its usual occurrences. This calculation method provides

Corresponding Author: Baiq Nurul Suryawati baiqnurul.suryawati@gmail.com

Received: 2 April 2018

Accepted: 17 April 2018

Published: 23 May 2018

Publishing services provided by Knowledge

(c) Baiq Nurul Suryawati et al. This article is distributed under the terms of the Creative Commons Attribution License, which permits unrestricted use and redistribution provided that the original author and source are credited.

Selection and Peer-review under the responsibility of the 1st ICSEAS 2016 Conference Committee. measurement that emphasizes how far the event happened based on its usual occurrence. Another measurement, however, called Value at Risk, comprise of several iteration to observe how likely the same event occurs that identified provide a better formulae to measure market risk. Thus, this research conducts the measurement of market risk based on Value at Risk with Monte Carlo Simulation. The research result there is no significantly different of market risk between indexes in which are Sharia and Non Sharia in Indonesian Stock Exchange. As also, this research result emphasizes that a decision to invest in Sharia and Non Sharia Capital Market depends on basic philosophy of investment, which is in this case, to conduct a comprehensive life of individual religion. In conclusion, this research predict possibility of market risk based on its daily trading stock market price, and calculate how likely it occurs in a thousand iteration. Based on the result that varies between several events of risk and return, as there is no difference between Sharia and Non Sharia, therefore the investment pattern will solely goes to preference of each individual based on their investment behaviour.

Keywords: Investment, Market Risk, Monte Carlo Simulation, Sharia, Value at risk

\section{G OPEN ACCESS}




\subsection{Background and objectives}

Capital Market offered various alternate of investment, as it provides various type of investment. In July 2000, Indonesian capital market offered sharia stocks, by the launch of Jakarta Islamic Index (JII) at Indonesian Stock Exchange (IDX). It designated to promote more opportunity for investors in Indonesia. This research furthermore highlighted the concept of investing in Islam. Some markets have opportunity to be serving by Sharia Market, such as Middle East Investors and some of Moslem Investors.

Based on IDX Statistics, stocks listed in Jll shows in some period, as in 2014, it shows highest greatest gain. However, the pattern was not consistent during 2012 until 2015. Table 1 compares JII with conventional stocks listed in LQ 45 which are comprises of 45 stocks that highly capitalize in Indonesian Stock Market (one of Stock Index in The Indonesia Stock Exchange) and IHSG (Composite Index of Indonesian Stock Exchange).

TABLE 1: Greatest Gain in Percentage from Indexes in IDX.

\begin{tabular}{|c|c|c|c|c|c|c|c|c|c|c|}
\hline \multirow[t]{3}{*}{ Index } & & \multicolumn{9}{|c|}{ Greatest Gain (\%) } \\
\hline & \multirow[t]{2}{*}{2012} & \multicolumn{3}{|c|}{2013} & \multicolumn{3}{|c|}{2014} & \multicolumn{3}{|c|}{2015} \\
\hline & & $\begin{array}{l}\text { One } \\
\text { Day }\end{array}$ & $\begin{array}{l}\text { One } \\
\text { week }\end{array}$ & $\begin{array}{l}\text { One } \\
\text { month }\end{array}$ & $\begin{array}{l}\text { One } \\
\text { day }\end{array}$ & $\begin{array}{l}\text { One } \\
\text { week }\end{array}$ & $\begin{array}{l}\text { One } \\
\text { month }\end{array}$ & $\begin{array}{l}\text { One } \\
\text { day }\end{array}$ & $\begin{array}{c}\text { One } \\
\text { week }\end{array}$ & $\begin{array}{l}\text { One } \\
\text { month }\end{array}$ \\
\hline IHSG & -0.98 & 1.54 & 2.97 & 4.51 & 1.56 & 6.59 & 4.32 & -12.30 & 9.07 & 1.85 \\
\hline LQ45 & -3.25 & 2.11 & 4.15 & 5.88 & 2.02 & 8.88 & 5.52 & -12.52 & 12.50 & 2.75 \\
\hline JII & -1.63 & 2.52 & 4.58 & 5.14 & 2.33 & 4.79 & 2.36 & -11.61 & 11.11 & 0.85 \\
\hline
\end{tabular}

Along December 2012, it shows varied changes between IHSG, whereas a lowest change from LQ 45, and followed by JII and IHSG. For 2013, 2014, and 2015, however it shows within one month in 2013, the highest gain achieved by LQ 45 . It different in 2014, where data gives information that $\mathrm{II}$ as indexes for favourable 30 stocks cannot over perform conventional market, thus in 2015 , Jll still under performed.

Separately from one-month data, one-day data of greatest gain put JII to over performed LQ 45, in continuously one-day event of 2013, 2014, and 2015. An inconsistent pattern shows how market in short-term investment valued $J I$ as representatives of Sharia Market better off than conventional market. It also shows that investors moved by their own return and risk preferences. It suggests that high risk and high return applied; therefore, capital gain is not solely the main consideration for investing in sharia market. The consideration for risk also applied. By comparing return and its 
standard deviation may not give the precise calculation for measuring how volatile each market was. Hence, another calculation of risk measurement conduct to aligning how return perceived by investors.

In order to support Sharia market, thus several researches in different term has conducted to compare the performance of Sharia market and Conventional market in Indonesia. Rachmayanti [2] tested the hypothesis of how sharia stock outperforms the conventional stock; however, it resulted a decline in 2002. The research also highlighted that sharia stocks in Jll outperform composite index. Moreover, shariascreening process proven had positive influence. It supports the result that shows significance difference between return and risk from sharia market and conventional market. Huda [3] conducted a research that shows beta as proxy for risk offer a lower risk in sharia market compares with LQ 45 during 2002 and 2003. Researches to compare sharia and conventional market continuously conduct to compare both markets, its conduct to get a description of both markets in Indonesia.

On the other side, risk could measure not only by calculating standard deviation from several series data of realized return but also by using value at risk. Bismark and Pasaribu [4] research results although Value at Risk (VaR) unable to show pattern between risk and liquidity, and it suggests the time span of portfolio formed extended as an addition to reach more reliable results. Thus, this research focused on measuring risk with value at risk to compare market volatility between sharia market and conventional market. Furthermore, this research was conducted to compare markets risk, whether there is difference of conventional and sharia market. It designs to support investment concept, as we know rely on trade-off between risk and return. As sharia market selected by certain procedure and has limitation in business sector that halal which based on Al Quran and Sunnah rule therefore business sector that has high risk such as conventional banks could not approved. As the part of its prohibitions, it suggests in certain return sharia market will result lowest risk.

\subsection{Method}

The study used data published by ECFIN (Economics and Finance Institutes) in ICMD (Indonesian Capital Market Directory) within 2014. Stock prices are a fraction of value of shares divided by its number. The stocks classified into two markets, sharia market and conventional market. Sharia market will represent by Jll and DES, and Conventional Market will represent by LQ 45. The portfolio will purely consists of all stocks that listed those indexes. This approach is to represent the volatility of each market based on its 
risk. Expected return is mean value of return from each period of indexes for six months in one financial year.

The usage of Monte Carlo simulation has several of algorithms. The simulation activates random number to estimate its VaR value. VaR calculation with Monte Carlo simulation conduct to assume that return from asset in a portfolio distributed normally by its multivariate factors. It simulated by suitable parameter and it assumed that its return is linear. A simple algorithm with Monte Carlo simulation in portfolio conduct by the stages below [5]:

- Defined parameter value for variables (in this research, its asset return) and its correlation. Assets return assumed to distribute normally. Therefore the parameter needed means the return of asset that form the portfolio, deviation standard of its asset that form the portfolio, and its variance covariance matrix

- Simulate return value and activate its random return of asset that distribute normally with parameter acquired in stage 1 for $n$ times

- Return value each asset in $t$ which are $R, t$ and $R 2, t$ as result in stage 2 as part of calculation for portfolio return at the time of $t$ :

$$
R_{p t}=\left(w_{1} \cdot R_{1, t}\right)+\left(w_{2} x \cdot R_{2, t}\right)
$$

$\mathrm{R}_{p t}=$ portfolio return at the time $\mathrm{t}$

$\mathrm{R}_{1, t}=$ Return asset 1 , at the time $\mathrm{t}$

$\mathrm{R}_{2, t}=$ Return asset 2 , at the time $\mathrm{t}$

$\mathrm{w}_{1}=$ proportion of asset 1

$\mathrm{w}_{2}=$ proportion of asset 2

- Calculate the estimation of maximum loss at level of confidence $(1-\alpha)$ as quintile value at $\alpha$ from empirically distribution of return portfolio acquired at stage 3 that notate by $R^{*}$

- Calculate VaR value at a certain level of confidence (1- $\alpha)$ within period of time t-days: $\operatorname{VaR}(1-\alpha)(t t)=W o R^{*} \sqrt{ } t$. The VaR results maximum loss of portfolio

- Repeat stage 2 until stage 5 for $m$ times that reflect various possibility of VaR portfolio which are VaR1, VaR2, .., VaRm, and $m$ value is number between 1 and the number of return from its single asset.

- Calculate mean return as result of stage 6 to stabilize the value as it VaR result shows different number in each simulation. 
The stages of Monte Carlo simulation and its analysis data apply in a Risk Analysis simulation by Microsoft excel with add-ins copyrights of Padjadjaran UniversityManagement Laboratory. The simulation will run 1000 iterations based on assumption made by series of data that represent mean value of historical expected return. Hence, it forecast the future value of return.

The hypothesis will test whether there are difference between risk measurement for sharia market and conventional market. Firstly, risk from each market will measure using VaR to find out whether the difference significant or not, a Manova test conduct in three groups of indexes. The indexes are JII, DES, and LQ 45. It tests procedures by stages below:

- Define variance of sample in hypotheses testing, in this research the parameters are Market Risk from JII, LQ 45, and DES

- Define hypotheses. This stage to answer the hypotheses proposed, therefore, it will be null hypothesis and alternative hypothesis:

i. Null Hypotheses (Ho): There is no significance difference from market risk of JII, LQ 45, and DES

ii. Alternative Hypothesis: There is significance difference from market risk of JII, LQ 45, and DES

- Define its level of significance, in this research, the level of significance is $\alpha=$ $0.05=5 \%$

- Set the test. Its test will be $\mathrm{F}$ test, which are calculate by formulae below:

$$
F_{\text {statistic }}=M S b: M S w
$$

$\mathrm{F}_{\text {statistic }}=$ value of $\mathrm{F}$

MSb = Mean Square between Groups

MSw = Mean Square within Groups

- Define critical area, critical point and area of acceptance.

i. Critical area or rejection area of $\mathrm{H}_{0}$ is area whereas if $\mathrm{F}_{\text {statistic }}$ in this area results rejection of $\mathrm{H}_{0}$

ii. Acceptance area of $\mathrm{H}_{0}$ is area outside critical area, whereas if $\mathrm{F}_{\text {statistic }}$ in this area then $\mathrm{H}_{0}$ will accepted

- Critical value of statistic testing will be in criteria below: 
i. If $\mathrm{F}_{\text {statistic }} \leq \mathrm{F}_{\text {table }}$ then $\mathrm{H}_{0}$ accepted and $\mathrm{H}_{1}$ rejected, it means that null hypotheses accepted. If $\mathrm{H}_{0}$ accepted it means that there is no significance differences between each parameter in this test, which are market risk from various groups, JII, LQ 45, and DES

ii. If $\mathrm{F}_{\text {statistic }} \geq \mathrm{F}_{\text {table }}$ then $\mathrm{H}_{0}$ rejected and $\mathrm{H}_{1}$ accepted, it means that alternative hypotheses accepted. If $\mathrm{H}_{1}$ accepted, it means that there is significance difference between each parameter in this test, which is market risk from various groups, JII, LQ 45, and DES.

\section{Limitations}

This research has limitation that it is only calculates risk as realize return recorded through historical differences stock price. It relies the result based on mathematic calculation and statistic iteration; therefore, it may not represent the investment behaviour, as there is no interview conduct with investment manager or a corporate staff etc. As it only conducts quantitatively, the result will observe how risk reflect return as stock price in each indexes which are JII, DES, and LQ 45 go higher or down as market perceives it values. A similar pattern of risk movement expected as it forms the stock price as return created by differences of stock price within certain period.

\section{Literature Review}

Tandelilin [6] defined capital market as intermediaries between surplus and deficit fund by trading the security, thus capital market by means is institution where's securities traded. Securities is defined as bond, stocks, and its derivative. Furthermore, in investment management Farrel [7] described several theories that was applied. Risk and return trade off identified as a foundation to implement capital market theory. The Table 2 shows the theory and its implementation.

Van Horne [8] defined risk as the variability of returns from those that are expects risk has two form whether deviant smaller or greater. Risk is variability of return that expected. Risks usually form as standard deviation that calculates the absolute value of deviant historical value and its mean value, in which known as expected return. Tandelilin [6] denoted that risk for expected return known as variance. Variance is square number of standard deviation. As square of standard deviation, variance has a single number as deviant of several differences between historical return and its expected return. VaR completed the measurement of standard deviation. 
TABLE 2: Theoretical Breakthrough Leading to Systematic Techniques for Investment Management [7].

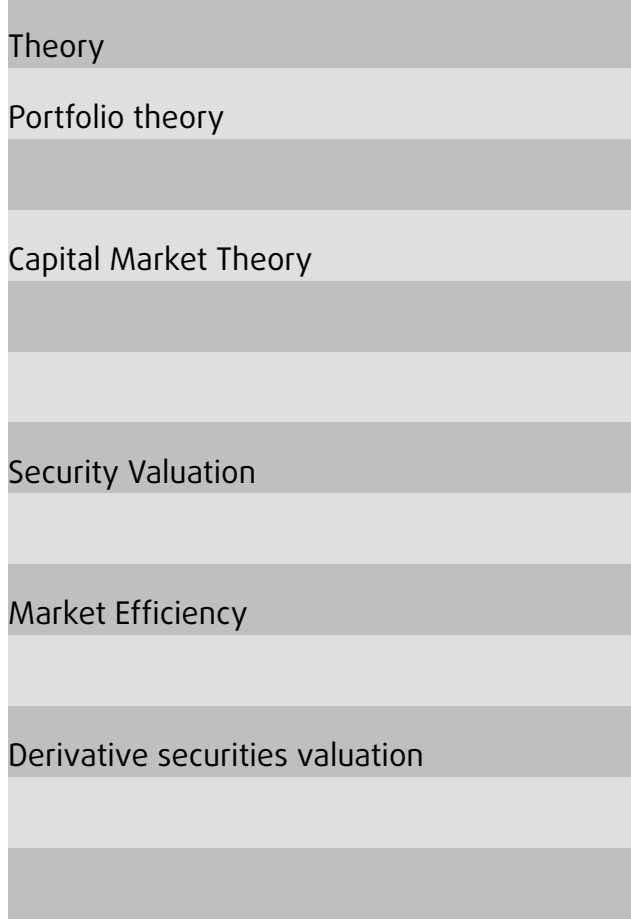

\begin{tabular}{|c|} 
Application \\
Asset allocation \\
Global Investing \\
\hline Risk Return trade off \\
\hline Portfolio Analysis \\
\hline Performance Measurement \\
\hline Dividend Discount model \\
\hline Market line \\
\hline Active/Passive \\
\hline Multiple valuation model \\
\hline Protective put \\
\hline Portfolio insurance \\
Index futures
\end{tabular}

Value at risk (VaR) is a method calculates market risk by setting maximum loss in a portfolio, which is single instrument or multi instrument in a certain level of confidence, within certain holding period in a normal market. Best [9] defines VaR as a method that statistically predicts the maximum loss that possibly happen in a certain level of confidence. VaR value follows by the probability that shows the possibility of loss that less than its value. VaR is also defined as a number that summarize total risk from portfolio that consists of various financial assets. It also stated by "what loss level is such that we are $x \%$ confident it will not be exceeded in $N$ business days?"

VaR superiority is its focus on downside risk; it is not depends on certain assumption of return. The measurement is also applicable to various financial products. A certain number of this measurement is a comprehensive calculation of risk. VaR is also estimates probability of loss which greater than loss that has been set before. This superiority of calculation is not applies in other method. VaR is also detecting changes of asset price and its influence. This method provides solution to measure how risk might get smaller by diversification of various product or portfolio. VaR has three methods of calculation, which are Historical Simulation Method, Variance-Covariance Method and Monte Carlo Simulation Method:

- Variance-Covariance Approach also known as delta normal method, it has superiority in simplicity of computing and implementation. The assumption used 
in Variance-Covariance Approach model is portfolio constructs based on linier asset. A change in portfolio is dependently linear with its return.

- Historical Simulation Method is the simplest and transparent in its calculation. It merely depends on a series of historical data that rank in order to get maximum loss number.

- Monte Carlo Simulation Method has superiority in its accuracy by its repetition using thousand iterations to calculate probability of chances of loss might happen. It weakness is due to its computation that take more time and length of data series.

\section{Findings}

Capital market in Indonesia activated by Indonesian Government in 1977, and its increased as various incentives and regulation created. It also promotes sharia capital market in 2000 to accommodate Moslem market in Indonesia. By methodology, this research measures market risk with VaR Monte-Carlo simulation. It will conduct a thousand iterations to measures probability of the return. It aligned with risk measurement based on deviation of a series of return data. The iteration will divide return as frequency classes and it will raise random numeric in order to get its statistic descriptive. Statistic descriptive will result mean value, standard deviation, kurtosis, skewness, and its normal distribution curves. Value at Risk, then, calculates by subtracting level of significance table value multiply standard deviation with its mean value. The result from several calculations conduct within indexes will serve by Fig 1.

The graph above shows how return varied from indexes observed. It shows the superiority of LQ 45 . In 2005, return gained by LQ 45 shows highest percentage, and almost in each bar LQ 45 shows it is higher than other indexes observed. However, in 2007 when DES firstly introduce then it shows different pattern, in 2013 DES shows it superiority, within the bar it shows DES has highest score than LQ 45. Therefore, it may assume as it results greatest return thus risk measurement by VaR will show same pattern. It may happen due to VaR measure risk based on its return and how it calculates it level of significance in normal distribution curve. VaR Monte Carlo simulation measures risk for each indexes, and it shown in the Fig 2.

The graph shows aligned trend between risk and return. As it discussed earlier, the pattern of risk resembling its return. Highest VaR is shows by DES in 2013, exactly as its return value. DES consists all of sharia stock in EDX therefore it results a greater 


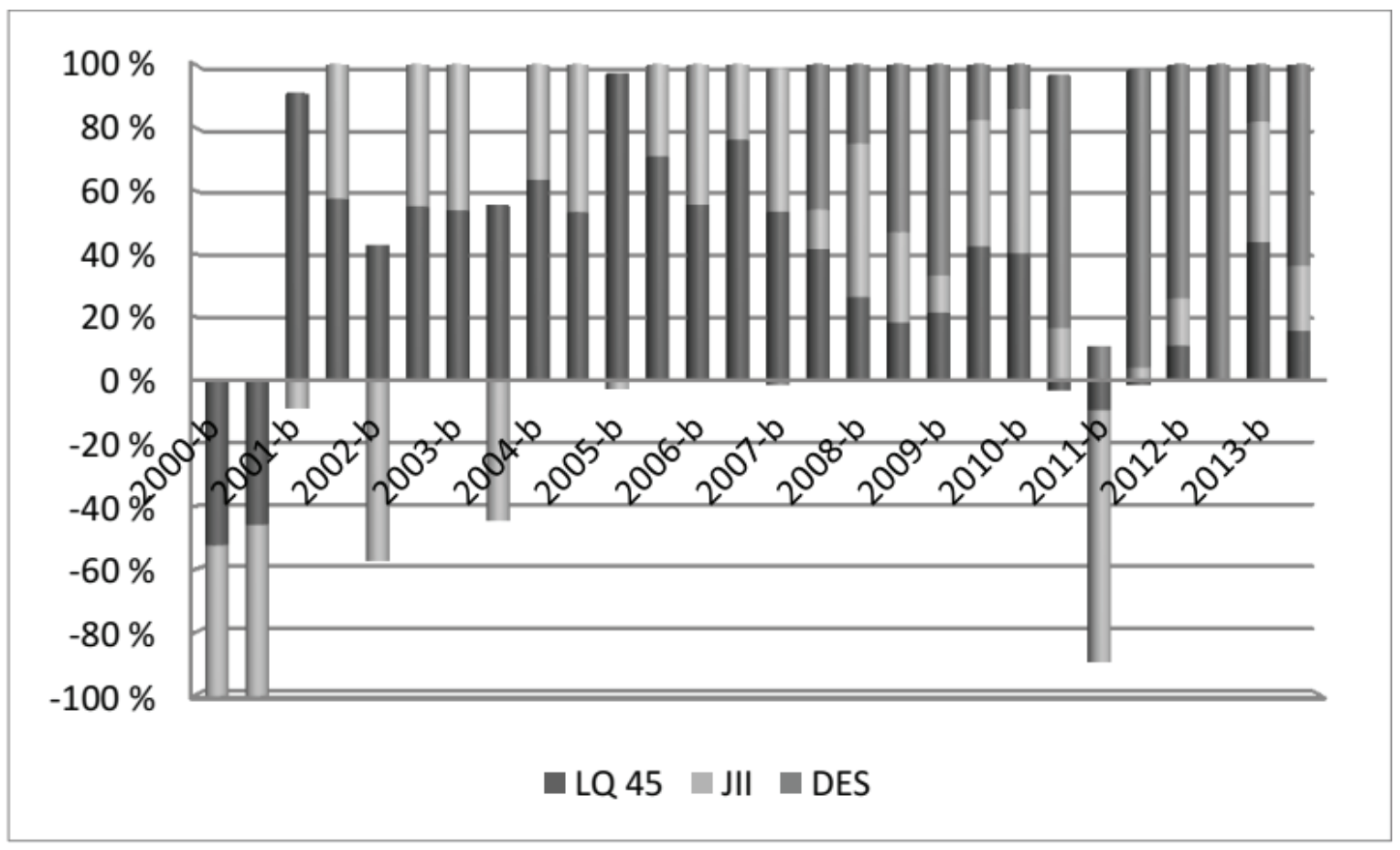

Figure 1: Return LQ 45, Jll, and DES within June 2000 until June 2014.

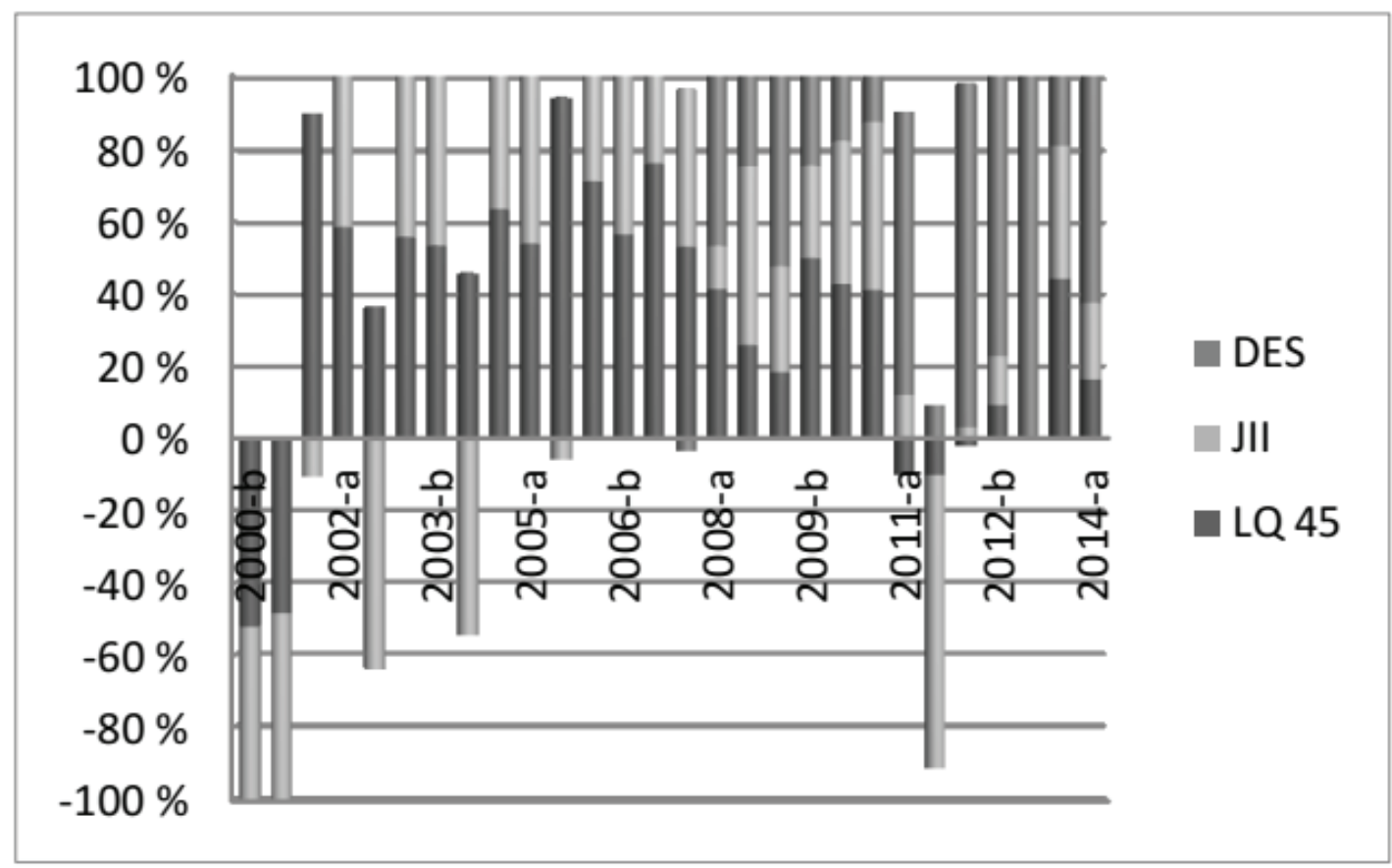

Figure 2: VaR as Market Risk Measurement for LQ 45, Jll, and DES within June 2000 until June 2014.

number the risk calculates based on variation of stock prices movement therefore a huge number of population my result greater number. To clarify the result, the table below will show summary of statistic descriptive of Return and VaR of JII, LQ 45, and DES. 
TABLE 3: Descriptive Statistics for Return and VaR of JII, LQ 45 and DES.

\begin{tabular}{|c|c|c|c|c|}
\hline & Portfolio & Mean & $\begin{array}{c}\text { Std. } \\
\text { Deviation }\end{array}$ & $\mathrm{N}$ \\
\hline Return & JII & 0.289 & 0.553 & 28 \\
\hline & LQ45 & 0.503 & 0.528 & 28 \\
\hline \multirow{4}{*}{ DES } & 8.459 & 27.086 & 14 \\
\hline \multirow{2}{*}{ VaR } & Total & 2.009 & 12.207 & 70 \\
\hline \multirow{2}{*}{ JII } & 0.257 & 0.535 & 28 \\
\hline & LQ45 & 0.462 & 0.498 & 28 \\
\hline & DES & 7.269 & 23.708 & 14 \\
\hline & Total & 1.741 & 10.671 & 70 \\
\hline
\end{tabular}

The Tabel 4 shows high return and high risk applied, as there is higher expectation applied, higher risk will follow. Based on table above, we could rank that DES gain highest return for mean 8.458 . The highest return comprises of a large number stock traded as part of DES. DES consists of 106 to 309 stocks, it also population of sharia stocks in IDX. The second will be LQ 45, in LQ 45, it comprises 45 stocks in conventional market that have most frequent trading and very liquid as it has highest capitalization among others. The lasts will be Jll, it comprises 30 stocks that highly traded among DES. In comparison of number stocks that include in each index, Jll will be the smallest, therefore return created from differences of today's stock price and previous stock prices will not result highest score. VaR calculates from return data, and similarly replicates its pattern. DES has highest risk, followed by LQ 45 and $\mathrm{Jl}$ at the last rank. Standard deviation from each return data shows greater number than its mean, it shows how diverse data from each other within period of observation.

Furthermore, to test how data above significance difference between sharia and conventional market, a manova test conduct. The multivariate test conduct to JII, LQ 45 and DES result Tabel 5 .

By the statistic test above, within four criteria of test only one which is Roy's Largest Root criterion that shows there is a significance difference between sharia and conventional market as other test show there are no difference, thus it concludes that there is no difference between sharia and conventional market. In each market which are most liquid conventional market, LQ 45; most liquid sharia market, JI, and populationall sharia stock, or sharia market, it shows only Roy's Largest Root has significance different. Although Field [10] mentioned how Roy's Largest Root in many cases may 
TABLE 4: MANOVA Test on JII, LQ 45, and DES (SPSS output copyrights of researcher).

\begin{tabular}{|c|c|c|c|c|c|c|}
\hline Effect & & Value & $\mathrm{F}$ & $\begin{array}{c}\text { Hypothesis } \\
\text { df }\end{array}$ & Error df & Sig. \\
\hline \multirow[t]{4}{*}{ Intercept } & Pillai's Trace & 0.077 & $2.744 b$ & 2 & 66 & 0.072 \\
\hline & Wilks' Lambda & 0.923 & $2.744 b$ & 2 & 66 & 0.072 \\
\hline & Hotelling's Trace & 0.083 & $2.744 b$ & 2 & 66 & 0.072 \\
\hline & Roy's Largest Root & 0.083 & $2.744 \mathrm{~b}$ & 2 & 66 & 0.072 \\
\hline \multirow[t]{4}{*}{ Portofolio } & Pillai's Trace & 0.120 & 2.141 & 4 & 134 & 0.079 \\
\hline & Wilks' Lambda & 0.880 & $2.179 b$ & 4 & 132 & 0.075 \\
\hline & Hotelling's Trace & 0.136 & 2.215 & 4 & 130 & 0.071 \\
\hline & Roy's Largest Root & 0.135 & $4.537 C$ & 2 & 67 & 0.014 \\
\hline \multicolumn{7}{|c|}{ a. Design: Intercept + Portofolio } \\
\hline
\end{tabular}

be the most powerful as it represents the most maximum possible between-group difference given data collected, a further analysis will conduct to verify the result. However, this result supports diversification theory that it needs an optimisation to make combination for construe a portfolio. A further post hoc test conducts to signify the difference for each market.

There are several conclusions based on the post hoc table, which are:

- Return JII and LQ 45 is not significant difference at level of significance 0.947

- Return JII and DES significant difference at level of significance 0.040

- Return LQ 45 and DES significant difference at level of significance 0.046

The post hoc test conduct also shows:

- VaR JII and LQ 45 is not significant difference at level of significance 0.942

- VaR III and DES is significant difference at level of significance 0.044

- VaR LQ 45 and DES is not significant difference at level of significance 0.051

A further analysis based on the statistical test provides result to support risk and return trade-off theory. VaR as measurement replicates how return data does. In definition, VaR is maximum loss that could tolerate by a company in certain level of confidence. Financial institution or bank mostly uses VaR. VaR with Monte Carlo simulation assumed that return distributed normally. VaR with simulation Monte Carlo 
TABLE 5: Post Hoc Test for Return and VaR (JII, LQ 45 and DES).

\begin{tabular}{|c|c|c|c|c|c|c|c|}
\hline \multirow[t]{2}{*}{$\begin{array}{l}\text { Dependent } \\
\text { Variable }\end{array}$} & \multirow[t]{2}{*}{ (I) Portofolio } & \multirow[t]{2}{*}{ (J) Portofolio } & \multirow[t]{2}{*}{ Mean Difference (I-J) } & \multirow[t]{2}{*}{ Std. Error } & \multirow[t]{2}{*}{ Sig. } & \multicolumn{2}{|c|}{$\begin{array}{c}95 \% \text { Confidence } \\
\text { Interval }\end{array}$} \\
\hline & & & & & & $\begin{array}{l}\text { Lower } \\
\text { Bound }\end{array}$ & $\begin{array}{l}\text { Upper } \\
\text { Bound }\end{array}$ \\
\hline \multirow[t]{6}{*}{ Return } & JII & LQ45 & -0.213908391061535 & 3.1913 & 0.947 & -6.584 & 6.156 \\
\hline & & DES & $-8.169379569379200^{*}$ & 3.9086 & 0.040 & $-15 \cdot 971$ & -0.368 \\
\hline & LQ45 & JII & 0.213908391061535 & 3.1913 & 0.947 & -6.156 & 6.584 \\
\hline & & DES & $-7.955471178317766^{*}$ & 3.9086 & 0.046 & -15.757 & -0.154 \\
\hline & DES & נ川 & 8.169379569379200* & 3.9086 & 0.040 & 0.368 & 15.971 \\
\hline & & LQ45 & 7.955471178317766* & 3.9086 & 0.046 & 0.154 & 15.757 \\
\hline \multirow[t]{6}{*}{ VaR } & JII & LQ45 & -0.204684415608171 & 2.7938 & 0.942 & -5.781 & 5.372 \\
\hline & & DES & $-7.011794189309167^{*}$ & 3.4217 & 0.044 & -13.841 & -0.182 \\
\hline & LQ45 & JII & 0.204684415608171 & 2.7938 & 0.942 & -5.372 & 5.781 \\
\hline & & DES & -6.807109773701090 & 3.4217 & 0.051 & -13.637 & 0.023 \\
\hline & DES & JII & 7.011794189309167* & 3.4217 & 0.044 & 0.182 & 13.841 \\
\hline & & LQ45 & 6.807109773701090 & 3.4217 & 0.051 & -0.023 & 13.637 \\
\hline \multicolumn{8}{|c|}{ Based on observed means. } \\
\hline
\end{tabular}

randomly provide iteration to forecast algorithm that predict the risk. A thousand iterations conduct in this research to predict how likely an occurrence happens in a 1000 experiments that randomly runs by a simulator. It implements, as VaR needs in order to anticipate market fluctuation.

Being part of risk management procedures, information of risk measurement will provide sufficient information to conduct a whole risk management procedure. The stages of risk management consist of several processes, which are identification, measurement, management assessment and controlling in predicting the possibility in future. Identification stages show different form of market, which are Sharia and Conventional market. Measurement of risk by VaR results as JII and LQ 45 has no difference in term of risk. This is due to both of indexes are benchmark for most liquid market in Sharia and Conventional market. Moreover, DES as the population of all sharia stocks in DES shows a different higher risk compare to its benchmark, Jll. Then, LQ 45 and DES show same higher risk although in return test it shows that both 
market, Sharia and Conventional market are significantly different. Findings above confirm that there is no significance difference among market with tendencies of higher risk in conventional market. It also supports the high return in conventional market by which in some circumstances whereas an open portfolio open for all stocks in sharia market result greater return. Investment in sharia market has differences in its operational concept. The differences may rely on:

- Sharia Investment has entity substance of investment aligned with Islam sharia based on Al Qur'an and Hadits

- Sharia investment has way of transaction aligned with sharia Islam as an entity

- Conventional market depends on investment concept based on usual practice of investment and community.

Alexakis and Tsikouras [11] emphasis the growth of the Islamic finance sector may be impacted by the increased involvement in Islamic finance by Western regulators, an existence of Islamic accounting procedures and increasing protection for stakeholders of Islamic Financial Institutions needed to support this system. The implementation of VaR with Monte Carlo simulation in this research will shows that in some term, as it may not violent main value of Islamic Economic. In this case, it also means the substance of investment whether it allows or not by Al Qur'an and Al Hadits, a measurement of risk may convince investors that Islamic finance give benefit as conventional investment. There are some regulation regarding how to invest such as filtering the substance of investment, avoiding scalping trading or investing in short term to speculate, which is underlying by the foundation of investment itself.

\section{Conclusions}

The statistic test supports basic investment theory whereas high return will compensate with high risk. However, as it differently tests Sharia market it shows different result for return and risk. By Manova testing, it shows that superiority DES in order to over performed LQ 45, as benchmark for most frequently trading stocks in conventional market. Moreover, it also shows how Jll as the benchmark for most liquid stock in Sharia market also differ from DES. On the contrary, by measuring market risk using VaR with the use of 1000 iterations to measure how likely an upside down occurrence happens based on its realize return results that risk in both market, Sharia and Conventional market are differ in some condition and not in other. Main findings that show how market risk differ between LQ 45 and DES but not with its return confirm 
that investors have chances to increase their return by participate in Sharia market with an expose to risk exactly the same as conventional market. For aggressive investors they could invest in JII, as benchmark for liquid stocks in Sharia market. At the end, the investors are having their own choice whether to invest in sharia market or not, as this research no significant differences between its risk and return. Investors who willingly to invest in sharia market may fully understand the procedure of investment sharia such as it is forbid to invest in certain kind investment. The investment may forbid based on product them sale, which also forbid in Al Quran and Hadits. Dewan Sharia Nasional has greater power to decide whether a stock is sharia category or not. An Investment in sharia Market will rely on each individual behavior as a Moslem not only as Investors. It also need to understand that investment in Sharia market must rely on underlying assets and are not based on speculation only. The restrictions on Sharia market are might cumbersome for some people. Therefore, a further research needed to discuss sharia investment on behavioral of finance perspective with depth interview to several investors or investment manager in order to pursue large information in order to strengthen Sharia market in the future.

\section{Acknowledgments}

Author would like to thanks to all people for their endless supports and honorable Research Institution of University of Mataram that helped providing us facilities so we could get the data and carried out this research.

\section{References}

[1] Research and Development Division. IDX statistics 2015. Indonesian stock exchange [Online] from http://www.idx.co.id/en-us/home/publication/statistic.aspx (2015). [Accessed on 12 Nov 2016].

[2] Rachmayanti TF. Analisis kinerja portofolio saham syariah [Performance analysis of sharia stock portfolio]. [Thesis]. PSKTTI (Study of Middle-East)-Faculty of Economics, University of Indonesia (2003). [in Bahasa Indonesia]. http://lib. ui . ac.id/file?file=pdf/abstrak-73820.pdf

[3] Huda N. Pasar modal syariah dan faktor yang mempengaruhi beta saham (studi kasus JII dan LQ 45 tahun 2002-2003) [Islamic capital market and influencing factors of beta shares (Case study JII and LQ 45 throughout years 2002-2003)]. [Thesis]. PSKTTI (Study of Middle-East)-Faculty of Economics, Universitas Indonesia (2003). 
[in Bahasa Indonesia]. http://lib.ui.ac.id/file?file=pdf/abstrak-73981.pdf

[4] Bismark R, Pasaribu F. Value at risk portofolio dan likuiditas saham [Portfolio's value at risk and stock liquidity]. Jurnal Akuntansi dan Manajemen-STIE YKPN Yogyakarta (Accountancy and Management Journal-STIE YKPN Yogyakarta) 2010; 21 (2): 105127. [in Bahasa Indonesia]. http://www.academia.edu/3988972/Value_at_Risk_ Portofolio_dan_Likuiditas_Saham

[5] Jorion P. Value at Risk: The new benchmark for managing financial risk. Mc GrawHill, Boston; 2002. Pp 245-377. https://merage.uci.edu/\$ $\$$ sim\$jorion/Answer. pdf

[6] Tandelilin E. Portofolio dan investasi: Teori dan aplikasi [Portfolio and investment: Teori and aplication]. Kanisius, Yogyakarta; 2010. p. 26-59, p. 101-155. [in Bahasa Indonesia]. http://library.um.ac.id/freecontents/index.php/buku/detail/portofolio-dan-investasi-teori-dan-aplikasieduardus-tandelilin-37132.html

[7] Farrell Jr JL, Reinhart WJ. Portfolio management theory \& application, Intern. Edn. Mc Graw Hill, Singapore; 1997. Pp 3-13. http : //opac . vimaru . edu .vn/edata/EBook/ 081105/Portfolio\%2oManagement.pdf

[8] van Horne JC, Wachowiz Jr JM. Fundamentals of financial management, financial times prentice hall; (2005). Bahasa Indonesia Edition: Prinsip Prinsip Manajemen Keuangan Edisi 12 Buku 2. Fitriasari D, Kwary DA [Trans.]. Salemba Empat, Jakarta; 2007. pp. 73-90. [in Bahasa Indonesia]. http://penerbitsalemba.com/v3/ book-display $\cdot$ php?id=130

[9] Best P. Implementing value at risk. John Wiley and Sons, West Sussex; 1998. pp. 32130. http://as .wiley. com/WileyCDA/WileyTitle/productCd-0470865962.html

[10] Field A. Discovering statistics using SPSS 2nd Ed. Sage Publication, Great Britain; 2005. Pp. 586-592.http://fac.ksu.edu.sa/sites/default/files/ktb_lktrwny_ shml_fy_lhs.pdf

[11] Alexakis C, Tsikouras A. Islamic Finance: Regulatory framework-challenges Iying ahead. International Journal of Islamic and Middle Eastern Finance and Management 2009; 2(2): 90-104. http://www. emeraldinsight.com/doi/pdfplus/10. $1108 / 17538390910965121$ 